\title{
A Solar Charger for Lead-Acid Batteries in an Autonomous PV System
}

\author{
Ersagun Kürşat Yaylac1 ${ }^{1 *}$ \\ $1^{*}$ Karabuk University, Faculty of Engineering, Departmant of Electrical and Electronics, Karabuk, Turkey, (ORCID: 0000-0003-0358-5617), \\ ekyaylaci@karabuk.edu.tr
}

(1st International Conference on Applied Engineering and Natural Sciences ICAENS 2021, November 1-3, 2021)

(DOI: 10.31590/ejosat.1010771)

ATIF/REFERENCE: Yaylac1, E.K. (2021). A Solar Charger for Lead-Acid Batteries in an Autonomous PV System, (28), 717-721.

\begin{abstract}
Photovoltaic energy is an intermittent energy source because the sun is gone away from evening to morning. Therefore, the batteries have a vital role in getting continuous energy sources for the autonomous system. The battery highly affects the cost of the system. Also, the life span of the batteries can not be sufficient for the consumers. At this point, the charging algorithm is so important because it protects the battery, the battery's life recycling, and the back cost time of the whole system. In this paper, a battery charger is designed to get an efficient autonomous photovoltaic system. The photovoltaic system is designed as two parallel panels, a DC-DC buck converter, and two series batteries. The lead-acid batteries are used because of the lesser cost. The lead-acid battery has three charge regions such as bulk, absorption, and float regions. The bulk region is examined for different irradiation levels in this study because the bulk region is more critical for the system's efficiency. The charge algorithm changes the duty cycle of the buck converter considering the available irradiation level. The photovoltaic charger should satisfy both the maximum power and proper charge operation for the related battery/batteries. The conventional perturb and observe algorithm is modified to eliminate drawbacks such as oscillation around maximum power and the wrong decision law when the irradiation changes. The modified perturb and observe algorithm is used as a photovoltaic charger, and the simulation results present the superiorities of the proposed method.
\end{abstract}

Keywords: Solar charger, Battery Control, Lead-acid battery, Buck converter, P\&O method.

\section{Otonom bir PV Sistemindeki Kurşun Asitli Piller için Solar Şarj Cihazı}

Öz

Fotovoltaik enerji, güneş battı̆̆ında kesildiğinden kesintili bir enerji kaynağıdır. Bu nedenle piller, otonom sistem için sürekli enerji kaynakları elde etmede hayati bir role sahiptir. Pil, sistemin maliyetini büyük ölçüde etkiler. Ayrıca pillerin kullanım ömrü tüketiciler için yeterli olamamaktadır. Bu noktada şarj algoritması çok önemlidir çünkü pili, pilin ömrünün geri dönüşümünü ve tüm sistemin geri dönüş maliyetini korur. Bu çalışmada, verimli bir otonom fotovoltaik sistem elde etmek için bir pil şarj cihazı tasarlanmıştır. Fotovoltaik sistem iki paralel panel, bir DC-DC dönüştürücü ve iki seri pil olarak tasarlanmıştır. Maliyeti daha düşük olduğu için kurşun asitli piller kullanılmaktadır. Kurşun-asit akü, yığın, emilim ve yüzer bölgeler gibi üç şarj bölgesine sahiptir. Bu çalışmada, yığın bölgesi, sistemin verimliliği noktasında daha kritik olduğundan farklı 1şınlama seviyeleri için incelenmiştir. Şarj algoritması, mevcut ışınlama seviyesini göz önünde bulundurarak dönüştürücünün görev döngüsünü değiştirir. Fotovoltaik şarj cihazı, ilgili pil/piller için hem maksimum gücü hem de doğru şarj işlemini sağlamalıdır. Klasik değiştir ve gözle algoritması, maksimum güç etrafındaki salınım ve ışınım değişikliğinde yanlış kontrol kuralı uygulama gibi dezavantajları ortadan kaldırmak için modifiye edilmiştir. Geliştirilmiş değiştir ve gözle algoritması bir fotovoltaik şarj cihazı olarak kullanılmıştır ve simülasyon sonuçları önerilen yöntemin üstünlüklerini ortaya koymaktadır.

Anahtar Kelimeler: Solar şarj cihazı, Batarya kontrol, Kurşun asit batarya, DC-DC alçaltıcı tip dönüştürücü, Değiştir\&Gözle Yöntemi.

*Corresponding Author: ekyaylaci@karabuk.edu.tr 


\section{Introduction}

The whole world, the researchers investigate how to get green energy without polluting the environment because fossil fuels are coming to an end soon (Delihasanlar et al., 2019). Also, fossil fuels cause environmental concerns, global warming, unfortunately. Renewable energy sources can thankfully solve the electrical energy demand. One of the more crucial renewable energy sources is photovoltaic (PV) energy. The sun power being able to get to the earth in one day is enough to power the world's total energy demands for one year (S. Hiwale et al., 2014). There is a severe increase as $4 \%$ global sharing and $13 \%$ installed PV capacity from 2015 to 2020 (Sinsel et al., 2020).

The PV system can be installed and/or used as a gridconnected (GC) or autonomous system. The grid-connected system is always preferred near the residential areas or the electrical transmission lines. On the other hand, consumers usually prefer to use the autonomous photovoltaic system in remote areas. The batteries may not be used for GC topology because there is always energy to be supplied grid-side. However, battery usage is an obligation for the autonomous PV system when the sun is gone away in the evening. There are many rechargeable battery types such as lead-acid (LA), NiCad, NiMH, LiCoO2, LiMn2O4 and LiFePO4 in the industry. LA battery can be preferred in the PV system due to having some advantages as satisfying high current, having low impedance, efficiency, tolerance to overcharge, and lowest cost (Hua et al., 2010; Padhee et al., 2016). In this paper, the LA battery is used due to the mentioned advantages.

The efficiency of PV panels is so low, known as 9-17\% (Abu Eldahab et al., 2014). Moreover, the available power can not be evaluated its maximum capacity properly if any algorithm does not use. The needed algorithm is called maximum power point tracking (MPPT) in the literature, and the algorithm necessity stems from the nature of the PV characteristics. On the other hand, the batteries need a charge algorithm known as a battery charger (BC) to protect themselves and their lifecycles. Because of these reasons, the PV system needs an interface, DC-DC converter, between the panels and battery. The type of used DC-DC converter should be selected concerning the produced and output voltage level. There are many studies about the PV charger in the literature, and some of them are summarized as follow.

A new $\mathrm{BC}$ is offered using the zero-current switching technique in the DC-DC buck converter (Chuang, 2010). The proposed $\mathrm{BC}$ can get soft switching and so low switching loss, stress. The fuzzy logic based proportional integral derivative (PID) controller is suggested for BC (Kumar et al., 2019). DSP controlled high frequency battery chager is proposed for PV systems (Özbay et al., 2015). In another study (Özbay et al., 2016), a resonant converter is offered for the battery charger in PV Systems. In (Koutroulis et al., 2004), the current measurement effect is reduced in the $\mathrm{BC}$ for the autonomous PV system. In (Motahhir et al., 2018), some PV parameters not provided by the manufacturer is determined first. Also, the incremental conductance (IC) algorithm is modified to prevent some drawbacks of the conventional IC. The same algorithm is also modified in (Belkaid et al., 2016; Tey et al., 2014) for zero oscillations and accurate response for changing irradiation conditions. In (Padhee et al., 2016), the synchronous buck converter is used as the interface between the LA and PV panel. LA battery is charged in two regions, bulk and float charge mode.
The same study (Yilmaz et al., 2018) is made for charging the battery quickly, reducing losses, and increasing the battery's life cycle. Another study for LA batteries (López et al., 2016) focuses on the controller design. The LA battery is charged into three regions by using the designed digital cascade PI loops.

In this paper, the classic perturb and observe (PO) method is improved considering the widely known drawbacks in the literature. A three-stage battery charge algorithm is used to charge the batteries. The maximum available power is transferred to the battery in the bulk region thanks to the modified PO (MPO) method. Therefore, the charge time can be decreased, and the efficiency of the system can be improved.

\section{Material and Method}

The photovoltaic system is designed as a mini solar system with two parallel panels having $280 \mathrm{~W}$, a DC-DC buck converter, and two series batteries of 100Ah. The minimum necessities such as a mini-fridge and several led lamps are considered for a home when the system is designed. However, the inverter or loads do not use because the main focal point is the PV battery charger. The autonomous PV system used in this paper diagram is given as in Fig. 1. The parameter of the system is tabulated as given in Table 1.

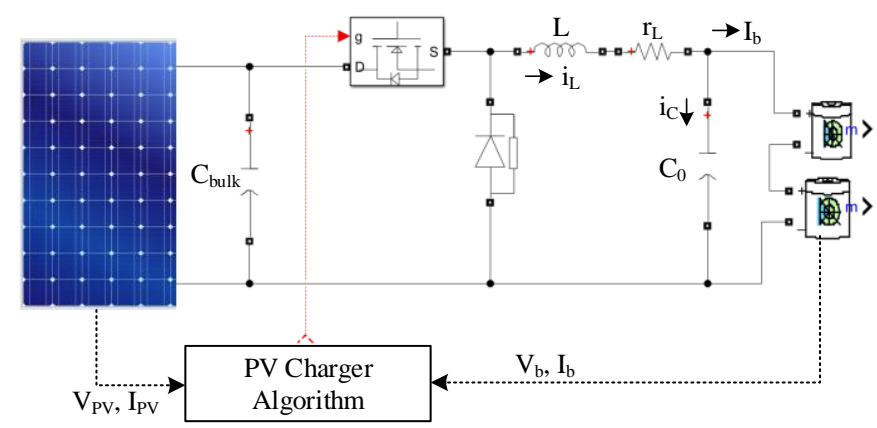

Fig. 1. The used PV System

Table 1. The parameters of the system

\begin{tabular}{|l|l|l|}
\hline \multirow{4}{*}{ PV panels } & Maximum power & $280 \mathrm{~W}$ \\
\cline { 2 - 3 } & Cells per module & 72 \\
\cline { 2 - 3 } & Open circuit voltage & $44.06 \mathrm{~V}$ \\
\cline { 2 - 3 } & Short circuit current & $8.23 \mathrm{~A}$ \\
\cline { 2 - 3 } & $\begin{array}{l}\text { Maximum power voltage for } \\
1000 \mathrm{~W} / \mathrm{m}^{2}\end{array}$ & $36.72 \mathrm{~V}$ \\
\hline \multirow{3}{*}{$\begin{array}{l}\text { Input filter } \\
\text { converter }\end{array}$} & Bulk capacitor & $150 \mu \mathrm{F}$ \\
\hline \multirow{2}{*}{ Battery } & Inductance & $200 \mu \mathrm{H}$ \\
\cline { 2 - 3 } & Parasitic resistance & $30 \mathrm{~m} \Omega$ \\
\cline { 2 - 3 } & Switching frequency & $20 \mathrm{kHz}$ \\
\cline { 2 - 3 } & Nominal voltage & $12 \mathrm{~V}$ \\
\hline
\end{tabular}

\subsection{PV System}

In this study, two parallel $280 \mathrm{~W}$ panels are used. The I-V and $\mathrm{P}-\mathrm{V}$ characteristics are presented for different irradiation level as in Fig. 2 and Fig. 3, respectively.

\subsection{The DC-DC Buck Converter}

The behaviour of the buck converter can be changed according to the switch on/off position. Considering the battery as a resistive load $(\mathrm{Rb})$ and neglecting the parasitic resistance to get an easier analysis, when the switch is on 


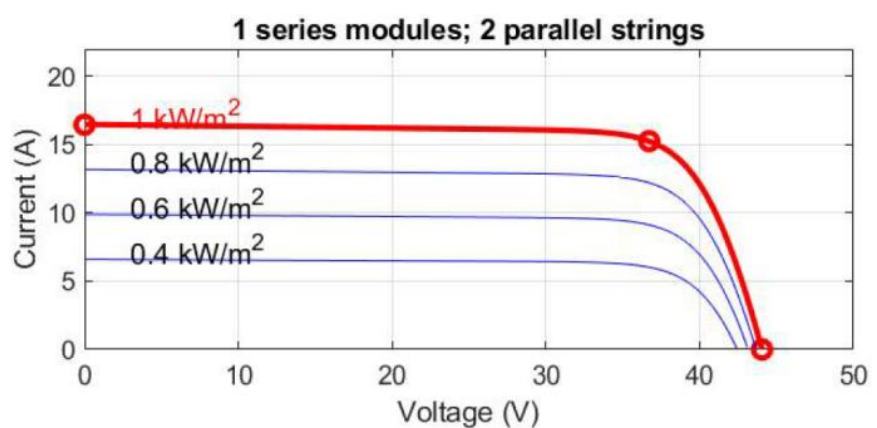

Fig. 2. I-V characteristics of the panels

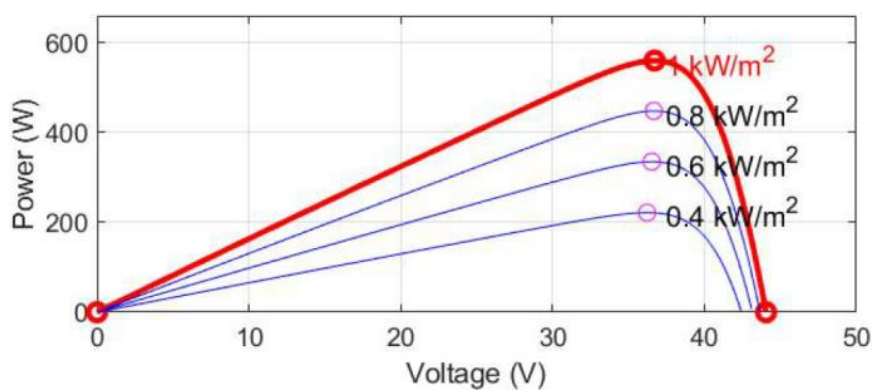

Fig. 3. P-V characteristics of the panel

$$
\begin{aligned}
& \frac{d i_{L}(t)}{d t}=\frac{1}{L}\left(V_{P V}(t)-V_{b}(t)\right) \\
& \frac{d V_{b}(t)}{d t}=\frac{1}{C}\left(i_{L}(t)-\frac{V_{b}(t)}{R_{b}}\right)
\end{aligned}
$$

where $i_{L}$ is the current of the inductor, $L$ is the inductance value, $\mathrm{V}_{\mathrm{PV}}$ is the panel voltage, $\mathrm{V}_{\mathrm{b}}$ is the battery voltage, $\mathrm{C}$ is the capacitance value, $R_{b}$ represents the battery. If the switch is off, Eq. 3 and 4 can be obtained easily.

$$
\begin{gathered}
\frac{d i_{L}(t)}{d t}=-\frac{V_{b}(t)}{L} \\
\frac{d V_{b}(t)}{d t}=\frac{1}{C}\left(i_{L}(t)-\frac{V_{b}(t)}{R_{b}}\right)
\end{gathered}
$$

By using Eq. 1-Eq. 4

$$
\begin{gathered}
\frac{d i_{L}(t)}{d t}=\frac{1}{L}\left(u V_{P V}(t)-V_{b}(t)\right) \\
\frac{d V_{b}(t)}{d t}=\frac{1}{C}\left(i_{L}(t)-\frac{V_{b}(t)}{R_{b}}\right)
\end{gathered}
$$

where $\mathrm{u}$ is the control signal of the switching device. The buck converter is designed as in (Kazimierczuk, 2016), and more detail is not given because it is out of scope for this study.

\subsection{Battery}

There are two LA batteries in series, as seen in Fig. 1, and the rated capacities are of $100 \mathrm{Ah}$. It has been already modelled in Matlab/Simulink environment. The LA batteries are charged in three different regions as bulk (Region 1), absorption (Region 2) and float (Region 3). In the bulk region, the algorithm should get the maximum available power from the PV source. The absorption region is used to protect the battery, and the maximum battery voltage is used to complete the charge operation in this region. The float region is used to prevent the discharge of the battery. Region 1 can be used to recover the battery approximately $80-90 \%$. In this study, the bulk region is examined because the operating time of the simulation program has a limitation. The flowcharts of the LA battery and bulk MPPT charging are given in Fig. 4 and Fig. 5, respectively.

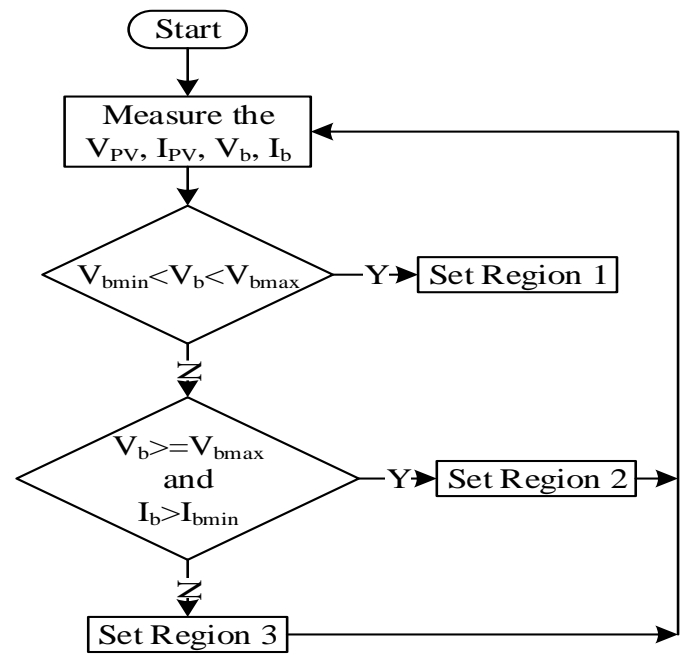

Fig. 4. The flowchart of the LA battery charging

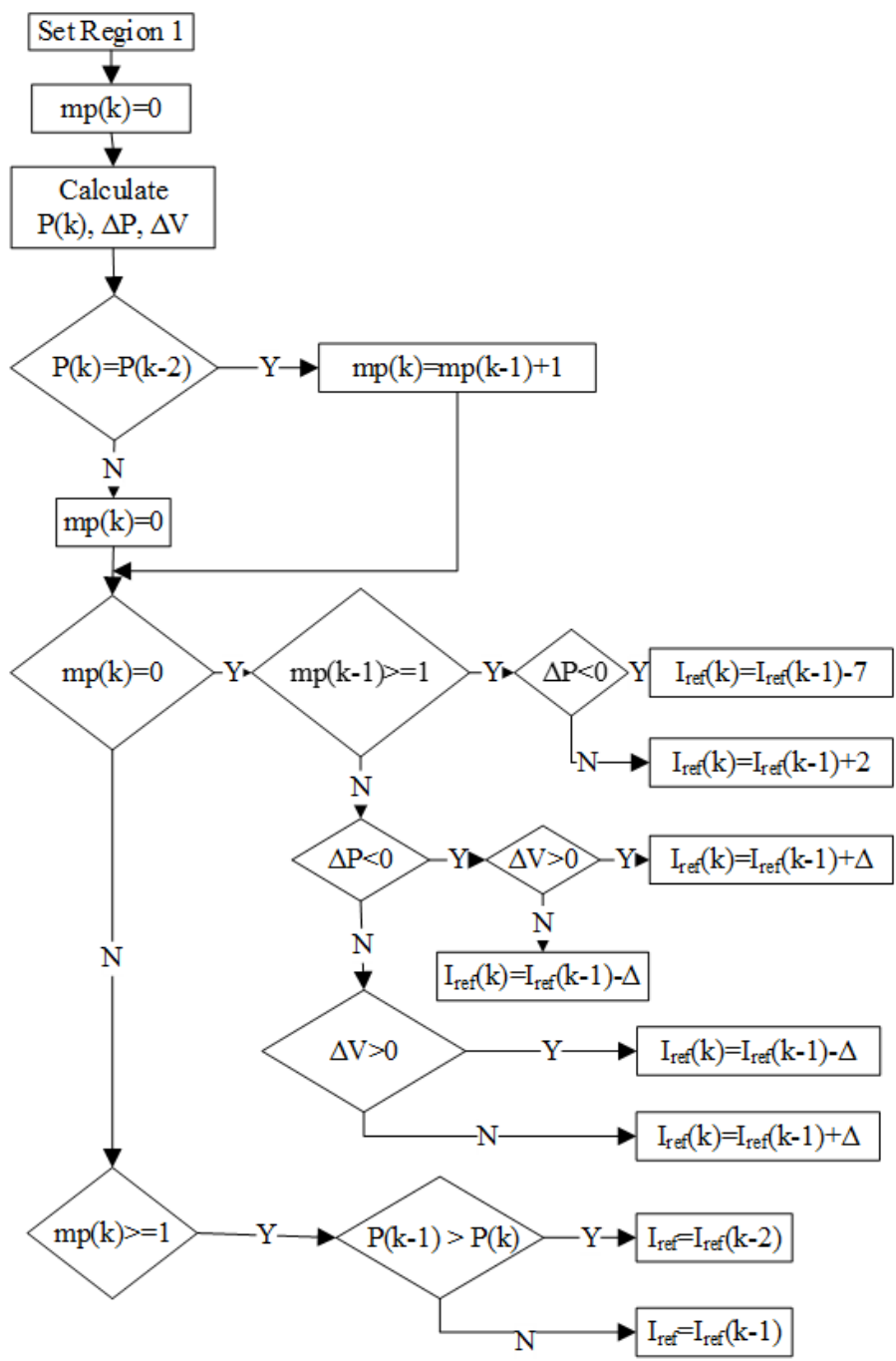

Fig. 5. The flowchart of the bulk MPPT charging 
Perturb and observe (PO) method, which is a search technique used to find a maximum point, is widely used in renewable energy systems (Yazıcı, Yaylacı, \& Yalçın, 2021; Yazıc1, Yaylac1, Cevher, et al., 2021). However, the wrong decision rule, selection of the optimum step size, etc., are the drawbacks of this method. Therefore, the PO method is modified considering the detection of the irradiation changing, prevent the oscillation around the maximum point, and using a bigger step size for the changing irradiation.

\section{Results and Discussion}

\subsection{Results}

The proposed PV battery charger is applied to the system considering the changing irradiation in Fig. 6.

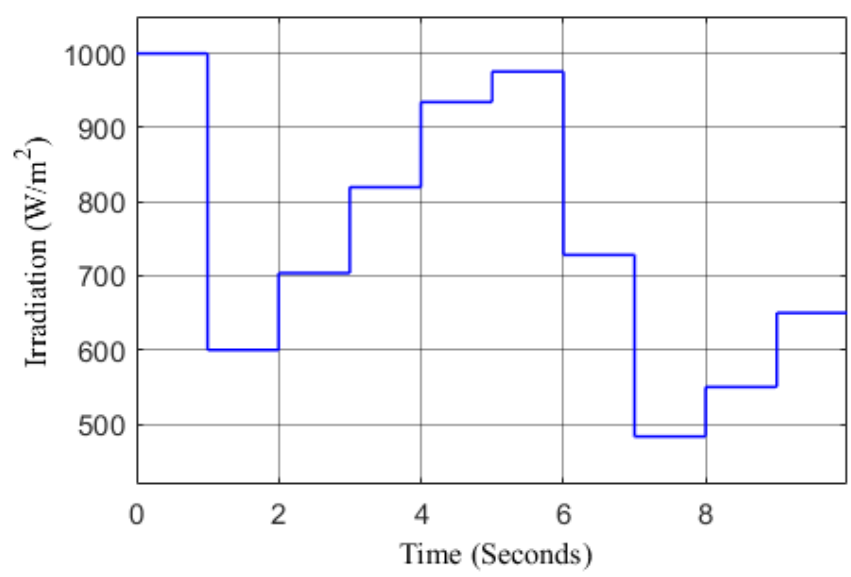

Fig. 6. Applied irradiation profile

Fig. 7 gives the produced reference current by the battery charging algorithm and the measured PV current. It can be easily seen that the controller can provide each desired current concerning the changing irradiation condition.

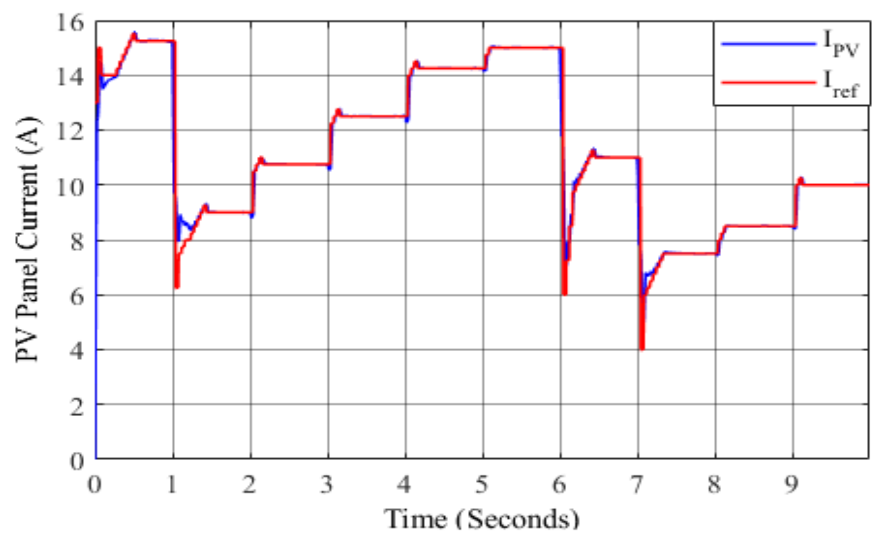

Fig. 7. The produced reference current and PV current

The initial state of charge of the battery is defined as $50 \%$ for simulation studies. The battery current and voltage are given in Fig. 8 and Fig. 9, respectively. The battery current is similar to the PV current except for the amplitude of the current as seen from Fig. 7 and Fig. 8.

The battery voltage starts from $24.2 \mathrm{~V}$ for the $50 \%$ initial state of charge. After the applied irradiation profile to the PV, the battery voltage has increased approximately to $24.6 \mathrm{~V}$.
Fig. 10 represents the produced power by the PV panels. There are also pieces of knowledge about some available power obtained from the manufacturer for changing irradiation conditions. One can see from Fig. 10 that for all applied irradiation values, the extracted power can satisfy the maximum available power.

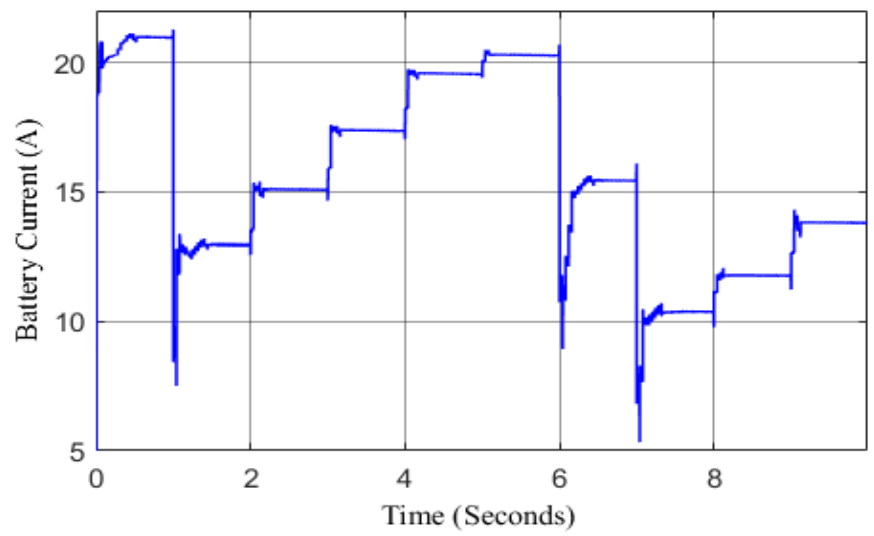

Fig. 8. The battery current for applied irradiation profile

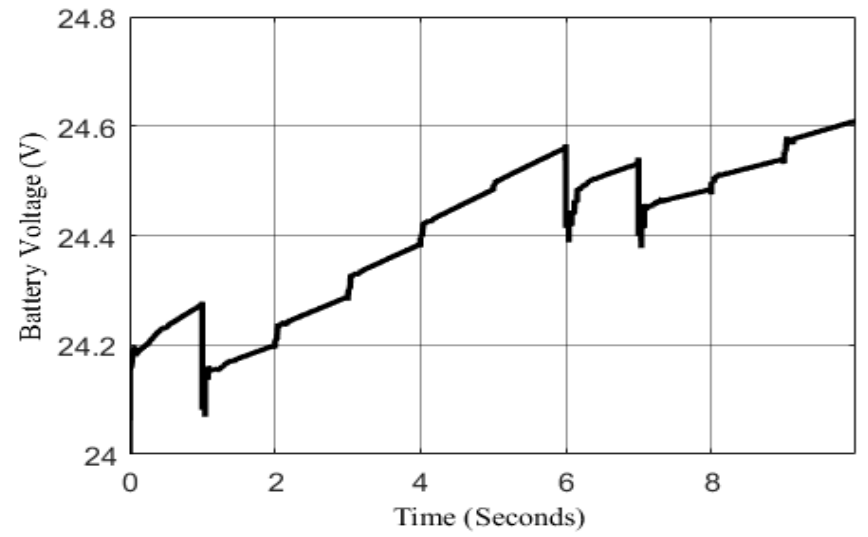

Fig. 9. The battery voltage for applied irradiation profile

Fig. 10 represents the produced power by the PV panels. There are also pieces of knowledge about some available power obtained from the manufacturer for changing irradiation conditions. One can see from Fig. 10 that for all applied irradiation values, the extracted power can satisfy the maximum available power.

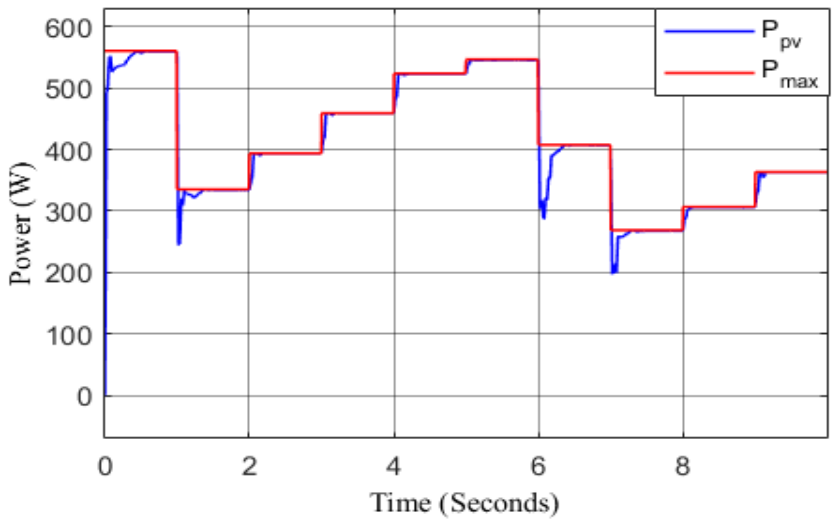

Fig. 10. Produced power by the PV panels

Fig. 11 shows the charge power of the battery. The power values of the battery are lesser than produced power because of the converter efficiency. 


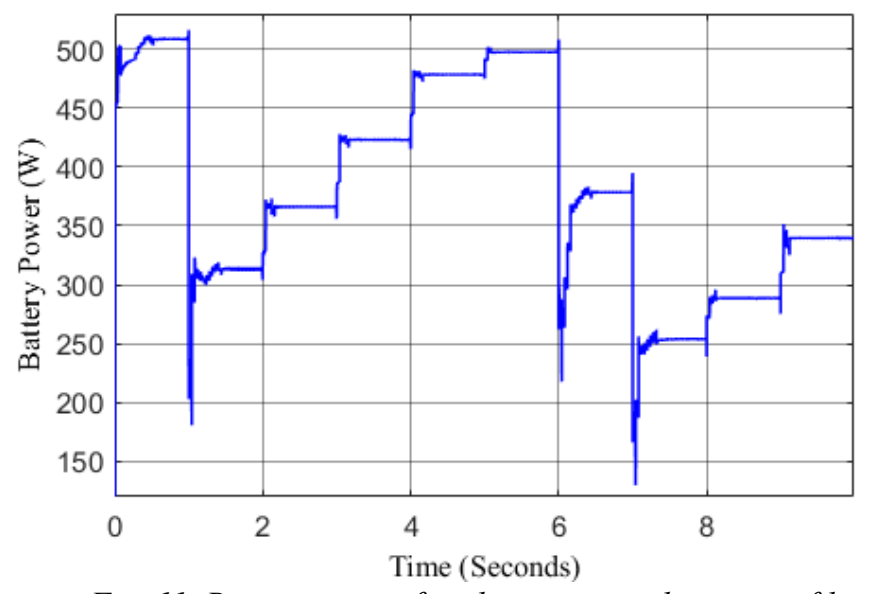

Fig. 11. Battery power for changing irradiation profile

\subsection{Discussion}

In this study, the PV charger algorithm is studied for the bulk region. The charge algorithm is rather crucial for the battery lifespan and protects the battery. Three-stage charge algorithms preferred in this paper is widely used algorithm. On the other hand, the drawback of the PO method, such as oscillation, wrong decision rule given in the literature, is prevented by the modified algorithm.

\section{Conclusions and Recommendations}

The efficiency of the PV system is so important because of the installation cost. Improve the efficiency of battery-based PV systems may contribute to the payback time. Moreover, an energy improvement provides lesser usage of fossil fuels and so lesser adversely effects on the environment. The classic PO method is modified, and it is proved that the proposed method can effectively get maximum power transfer to the battery despite the changing irradiation conditions. For the future studies, the experimental setup can be tested for the offered control strategies.

\section{References}

Abu Eldahab, Y. E., Saad, N. H., \& Zekry, A. (2014). Enhancing the maximum power point tracking techniques for photovoltaic systems. Renewable and Sustainable Energy Reviews, 40, 505-514.

Belkaid, A., Colak, I., \& Isik, O. (2016). Photovoltaic maximum power point tracking under fast varying of solar radiation. Applied Energy, 179, 523-530.

Chuang, Y. C. (2010). High-Efficiency ZCS Buck Converter for Rechargeable Batteries. IEEE Transactions on Industrial Electronics, 57(7), 2463-2472.

Delihasanlar, E., Yaylac1, E. K., \& Dalcalı, A. (2019). Dünyada ve Türkiye'de Güneş Enerjisi Potansiyeli, Mevcut Durumu, Teşvikleri, Kurulum Maliyeti Analizi-Karabük İli Örneği. Electronic Letters on Science \& Engineering, 15(1), 12-20.

Hua, A. C. C., \& Syue, B. Z. W. (2010). Charge and discharge characteristics of lead-acid battery and LiFePO4 battery.
International Power Electronics Conference, 95, 14781483.

Kazimierczuk, M. K. (2016). Pulse-Width Modulated DC-DC Power Converters (Second edi). John Wiley \& Sons, Ltd.

Koutroulis, E., \& Kalaitzakis, K. (2004). Novel battery charging regulation system for photovoltaic applications. IEE Proceedings-Electric Power Applications, 151(2), 191197.

Kumar, P., \& Kumar, A. (2019). Design of battery charging circuit through intelligent MPPT using SPV system. Solar Energy, 178(July 2018), 79-89.

López, J., Seleme, S. I., Donoso, P. F., Morais, L. M. F., Cortizo, P. C., \& Severo, M. A. (2016). Digital control strategy for a buck converter operating as a battery charger for standalone photovoltaic systems. Solar Energy, 140, 171-187.

Motahhir, S., Ghzizal, A. El, Sebti, S., \& Derouich, A. (2018). Modeling of Photovoltaic System with Modified Incremental Conductance Algorithm for Fast Changes of Irradiance. International Journal of Photoenergy, 3286479, $1-13$.

Özbay, H., Karafil, A., \& Öncü, S. (2016). Simulation of Battery Charger using a Resonant Converter for PV Systems. 8th International Ege Energy Syposium, 89-93.

Özbay, H., Karafil, A., Öncü, S., \& Kesler, M. (2015). DSP Controlled High Frequency Battery Charger for $\mathrm{Pv}$ Generation Systems. European Conference on Renewable Energy Systems, 7-10.

Padhee, S., Pati, U. C., \& Mahapatra, K. (2016). Design of photovoltaic MPPT based charger for lead-acid batteries. International Conference on Emerging Technologies and Innovative Business Practices for the Transformation of Societies, 351-356.

S. Hiwale, A., V.Patil, M., \& Vinchurkar, H. (2014). An Efficient MPPT Solar Charge Controller. International Journal of Advanced Research in Electrical, Electronics and Instrumentation Engineering, 3(7), 10505-10511.

Sinsel, S. R., Riemke, R. L., \& Hoffmann, V. H. (2020). Challenges and solution technologies for the integration of variable renewable energy sources - a review. Renewable Energy, 145, 2271-2285.

Tey, K. S., \& Mekhilef, S. (2014). Modified incremental conductance MPPT algorithm to mitigate inaccurate responses under fast-changing solar irradiation level. Solar Energy, 101, 333-342.

Yazıcı, İ., Yaylacı, E. K., Cevher, B. B., Yalçın, F., Yüzkollar, C. (2021). A new MPPT method based on a modified Fibonacci search algorithm for wind energy conversion systems. Journal of Renewable and Sustainable Energy, 13(013304), 1-11.

Yazıcı, İ., Yaylacı, E. K., \& Yalçın, F. (2021). Modified golden section search based MPPT algorithm for the WECS. Engineering Science and Technology, an International Journal, 24(5), 1123-1133.

Yilmaz, U., Kircay, A., \& Borekci, S. (2018). PV system fuzzy logic MPPT method and PI control as a charge controller. Renewable and Sustainable Energy Reviews, 81, 994-1001. 